\title{
Joan Miro and the Ancient Catalan Art
}

\author{
Ksenia Orlova \\ Department of Contemporary Art of the West \\ State Institute of Art Studies \\ Art Historians Association (AIS Ltd.) \\ Moscow, Russia \\ E-mail: ks@oskom.ru
}

\begin{abstract}
The following article describes Joan Miro's inseparable connection with Ancient Catalonian art, with the lands of Montroig and Palma de Mallorca. It shows how Catalonian culture influenced the artist's style and made the essence of his art.
\end{abstract}

Keywords-Miro; Catalonia; Montroig; Catalan artist; ancient Catalonian art; Romanesque art; surrealism; artistic language

\section{INTRODUCTION}

The art of Joan Miro is closely connected with the history, culture and nature of Catalonia.

Joan Miro (Joan Miró i Ferrà) was born on April, $20^{\text {th }}$, 1893 in Barcelona in a family of Miguel Miro-Asderias and Dolores Ferra. At that time his parents were living in Passatge del Credit., 4, in the very centre of the Gothic Quarter. Neither of them was from Barcelona, Dolores Ferra was a daughter of a cabinet-maker from Palma de Mallorca and Miguel Ferra - a goldsmith and a watchmaker - was born in a village Cornudelle in Tarragona, $150 \mathrm{~km}$ to the south of the capital of Catalonia. These places had a deep influence on Miro's formation as an artist. One of the main factors that influenced the artist's philosophy was amazingly harmonious architecture of Barcelona: wide tree-lined streets, round squares, boulevards with unusual buildings designed by Moodernist architects such as Antoni Gaudi, Luis Dominic i Montaner, Josep Puig and i Cadafalc etc.

\section{CHILDHOOD AND YOUTH OF MIRO}

As a child Joan Miro spent a lot of time visiting his grandparents and enjoying the nature of Catalonia and Mallorca. Joan liked watching insects, birds, lizards, trees and all these objects later appeared in his art and became characteristic features of his artistic language. Picturesque trees grow in the mountains of Catalonia such as macchia, oaks and pine trees and at the seaside you can see Miro's favourite agaves, lilies, prickly pears and a great number of palm trees planted here in the 19th century. Hilly spaces between the Mediterranean seaside and the mountains are covered with cork oaks and evergreen oaks and olive trees. There are gardens and fields with rich soil. Windy mountain roads, rivers, lakes, valleys - all this diverse nature was reflected in numerous Miro's landscapes. He had long walks and painted a lot while walking. Whole albums of his accurate but not much notable sketches survived - landscapes of Montroig, pictures of bridges, windmills, trees ("Cornudella", 1906 and "Porrera (Tarragona)", 1906).

At some point painting became his main passion and in 1907 Joan Miro signed up for a drawing workshop of Modest Urgell i Inglado 1 in La Llotja - an art school in Barcelona. That's what Miro wrote about his teacher later: "Modest Urgell - my first teacher - had a big influence on me, cultivating in me love to solitude and style without excessiveness, which is always present in my works" [2, p.15-16]. Urgell's works were notable for his lyricism and a feeling of loneliness.

At the same school Miro attended workshops of another Catalan artist who played an important part in formation of his world view - a teacher of decorative and applied arts Jose Pasco i Mensa2. He went with the students on plein air

\footnotetext{
${ }^{1}$ Modest Urgell i Ynglada (1839-1919) - a painter and a playwright. A student of Ramon Marti I Alcin. Urgell was one of the first painters who took a student trip to Paris instead of Rome. He spent their one season where was influenced by Gustav Courbet Realism. His works being ahead of the time were rejected and not understood at exhibitions organized in $\mathrm{La}$ Llotja and in Madrid. In 1870 he went to Olot (an area in Gerona region in Catalonia) where he met Joaquim Vayreda i Vila (1843 - 1894), a Catalonian painter, one of the founders of Catalonian landscape art of the $19^{\text {th }}$ century. Influenced by him, Urgell dedicated himself to painting landscapes. He regularly exhibited his works in Sala Pares from the moment when it was founded in 1877 and was successful in national exhibitions Madrid in 1876, 1892 and 1895 where he won his first medal for the work "Pedregal, a Developed City" and was also awarded the highest prizes for exhibitions in Barcelona 1894, 1896 and 1898, he took part in Philadelphia and Munich, Catalonian National art museum, Gerona, Palma de Mallorca, Lugo, Hamburg Art museum etc. He was the founder of Catalonian Art and Literature society. From 1894 he taught to paint landscapes in La Llotja. His most works are landscapes and marinas full of sad and mysterious atmosphere. There are also monasteries and abandoned places in his paintings. Sometimes his works are compared with those of Arnold Beklin. As a writer he published several plays "Far away from eyes" (1898), "Sugar" (1898), "Yearning!" (1899), "For" (1901), "Value" (1907); and in 1913 he wrote his autobiography "Bat. Memoirs of a patum", In 1902 he was elected an academic of Barcelona Art Academy.

${ }^{2}$ Josep Pascó Mensa (1855-1910) - a designer, a graphic artist and a set designer. He started as a muralist. He studied at La Llotja under Simo Gomez and also under Josep Planella, a stage designer. He painted landscapes, illustrated books, designed jewellery and was a stage designer. In 1887 he went to Madrid where he worked for the Royal theatre, he was also a stage designer at Prince Alfonso Theatre. In 1896 he went to Mexico to design stage set for National Theatre. Then he returned to Europe and worked as art and literature journals illustrator such as "Art and Literature" and "Catalonian Illustration" under a pseudonym Brisa. He designed interiors such as Ramon Cazas house in Barcelona. He was a professor of
} 
painting, organized poetical evenings. Later poetry would be part of Joan Miro's life and he would plunge into the world of poetic and surreal dreams. While studying under Jose Pasco Miro worked as a designer and designed jewellery, e.g. "Snake" ("Serpiente", 1908). Jose Pasco taught young artists to create using their own imagination, to be spontaneous in their work, to trust their intuition. He underlined the importance of the colourful traditional Catalonian art to which Miro would be committed all his life.

In 1910 Miro fell seriously ill and his parents decided to send him to recover for several months on a recently bought farm Montroig situated in a small village $(140 \mathrm{~km}$ from Barcelona). He often repeated later: "Everything that happened to me originates from Montroig" [2, p.13].

In 1911 Miro entered private Art Academy Gali (Escuela de arte de Francesc d'Assís Galí i Fabra) in Barcelona, which was considered a very progressive one. Its founder Fransesc Gali3 provided education based on anti-academic methods, trying to develop in his students creative individuality, artistic independence and freedom of expression. Gali paid attention not only to art teaching, but also to broadening his students' outlook, refining their taste for drama and poetry. Miro recalled in his conversation with Georges Raillard: "Gali was an open-hearted man who had a very broad scope of knowledge. Every Saturday we went to the countryside with Gali and his colleagues from the workshop. The most important thing was not sketches on plein air, but our conversations. In the evening when we returned, we played music or recited poems. As you see, it was more than learning skills and techniques. It was at the academy, not in the family, where I developed passion for poetry" [3, p.23]. Music played an important part in students' formation. Concerts and choir performances often took place at the academy and Chamber Music Society founded by Gali in Barcelona always reserved seats for its events for the academy students.

The whole group of Gali's students studied works by great masters of the past. They paid special attention to ancient Catalonian art.

\section{MIRO AND THE ANCIENT CATALONIAN ART}

At the end of the $19^{\text {th }}$ century European artists started getting interested in the culture of far-away countries as well as in their own national roots. It was connected with the desire to renew artistic language or even sometimes create a new one, the desire to find appropriate methods to express the ideas which were in the air. Rediscovering traditional ways of expression became widespread. Artists discovered

Higher Art and Industry school in Barcelona and "Barcelona" journal artistic director.

${ }^{3}$ Francesc d'Assís Galí i Fabra $(1880$-1965) - a Catalonian artist and teacher. He studied etching at La Llotja under Alexandre de Riquer i Ynglada (1856-1920). He was influenced by Realism, Symbolism and some Modernist movements. He spent large sums of money to support young artists' studies. In 1906 he founded an art school with non-academic approach to teaching. In 1929 he was appointed an art adviser at International exhibition in Barcelona for which he produced a poster. During the Civil War in Spain he was Minister of Culture. In 1939 he emigrated to London.
Japanese prints, primitive and traditional art - every nation had its own art. For example, culture and nature of the islands of Oceania (Tahiti and Hiva Oa) inspired Paul Gaugin, African culture influenced cubists, Indian civilizations had an impact on American abstractionists, primitive art played an important role in the development of Russian avant-garde.

It's necessary to mention that rediscovering the past had happened before. Romantic artists were interested in myths and they even understood myth as an ideal of romantic art; symbolical understanding of the world, using folklore and idealising the past and ancient cultures were characteristic of romanticism. Those were reasons why they loved painting ruins, idyllic landscapes of ideal Ancient Rome and Greece. But the artists of the $20^{\text {th }}$ century didn't need this 'ideal', they looked for naturalness, primitivity, savagery and they found them in old cultures, in the art of African tribes or Indians. Avant-garde artists turned back to the roots discovering treasures of the artistic language both in faraway exotic cultures and in cultures of their ancestors.

Joan Miro wasn't an exception. The artist turned to the ancient Catalonian art which he knew from his childhood. He said in an interview: "I often watched those Romanesque frescoes because when I was a child, every Sunday morning I was taken to Romanesque Art Museum in Montjuic" [3, p.71]. Even when Miro grew up, he kept this habit: "When I was 8, when I was 10 I went to Romanesque Art Museum on my own on Sunday mornings. I was crazy about it. Apart from Catalonian frescoes there was a room with catacomb paintings, I didn't forget about it either" [3, p.25].

Miro was impressed by the ornaments in Ancient Catalonian art which were influenced by the Mauritanian art. Having defeated the Arabs and transforming prayer towers into bell towers and mosques into churches, Christians kept examples of Mauritanian style for the future generations and they often took into account 'Mauritanian style' when building new churches. It clearly revealed itself in the predominance of ornaments in the decoration of churches. The ornament was placed as large colourful spots on the surface of blind walls and was marked by extraordinary colourfulness and inventive power present in Mauritanian art. The source of inspiration for such ornaments could be Mauritanian pottery the characteristic of which is extreme density of painting like in textile painting of Eastern-style carpets. Real and fantastic beasts, fights between Spanish knights and Arabs, imaginative coats of arms and pseudoArabic inscriptions are mixed in pottery and silk decorative elements. In general, ornaments with their quite large variety of patterns played one of the main parts. Images of all kinds of fantastic beasts, where human shapes were mixed with animal images, were particularly loved. Their sources were different: it could be barbaric heritage or heritage of Ancient Greece and Rome, Byzantium, Iran, rarely Far East. Possible sources of inspiration were imported arts and crafts objects and miniatures.

At the beginning of the $20^{\text {th }}$ century ancient art became a powerful stimulus for changes of many artists' style. Ancient Catalonian art was such a stimulus for Miro. Looking for 
new ideas he turned to artistic tradition of his ancestors. The discoveries which he made watching the works of Medieval masters - especially of Romanesque art - captured him and broadened the capability of his artistic language. He recalled: 'I admired Romanesque frescoes. They are superb. Angels are especially striking, they have eyes everywhere.' For example, on a fresco from the apse of Saint Clement's church in Taüll "Lion and Saint Mark" of the $12^{\text {th }}$ century ("Fresco románico del ábside de Sant Climent de Taüll: el león y el ángel de San Marcos"). Maybe that's where such attention to eyes in his surreal works came from, even a tree can have eyes - "Tree hears and sees" [3, p. 73]. Catalonian frescoes are full of ethereal atmosphere and mystery, but at the same time they are spontaneous and naive, their special features are large eyes (which impressed Miro so much), clearly defined faces, simple postures and gestures of the characters, tough, figures outlined with black colour, local and quite basic colour (brick red background, ochre, olivegreen and bright blue colours).

Watching frescoes ${ }^{5}$ the artist paid special attention to stylized animal figures whose parts (head, eyes, neck) have in Catalonian tradition purely ornamental character, they often include non-figurative elements (e.g. ribbon weaving). This method would be widely used by Miro in his Surrealistic period. They were Surrealists who paid much attention to ancient art while Catalonian artists concentrated on Romanesque art.

Surrealists were mostly attracted by Romanesque masters' love for the fantastic, obscure, sometimes even monstrous.

Romanesque frescoes are famous for their accentuated graphics and solid lines as well as for the strict range of colours. Images are outlined with black colour, volume modelling is minimal. Art is dominated by stylized-twodimensional method, it's marked by unusual sharp expression and some austerity. The influence of such tendencies could be later discovered in Miro's works, e.g., in "Ricard's Portrait", 1916, where use of local colour is evident and you can see hands and faces outlined with black colour - a method so much reminding ancient Catalonian frescoes.

Miro also admired allegorical character and symbolism of Romanesque art. Umberto Eco wrote: "Medieval people really lived in a world full of mysterious meanings, allegory, metaphors and God's signs which could be found in the things around them. The world around them constantly talked to them in the language of heraldry where a lion was not only a lion, a nut - not only a nut and a winged horse was as real as a lion because like a lion it was a symbol of a supreme reality though it didn't exist as everyday experience". Like Medieval artists Miro tried to connect the image and its meaning through direct analogy, to connect the

\footnotetext{
${ }^{4}$ Sant Climent de Taüll is located in Taull in the municipality of Valley of Boi, in the province of Lleida, Catalonia, Spain.

${ }^{5}$ The word 'fresco' is not quite relevant to these works as only the first layer was painted over wet plaster, all the other layers were painted with tempera over dry plaster, but the author will use this term for the purposes of convenience.
}

symbol and its gradually revealed meaning. The fact that he draws using his imagination doesn't let him move any important line of the object which transferred from the outer world into memories. For Miro it's important to prevent emotion which create in him tension and struggle from transforming into enthusiasm without any reason. The beauty of his works, the creator of new myths, originates from two sides of his character, which mix together and follow the same development process: strength capable of achieving exalted state of mind and an ability to study it deeply and to analyse situation in which he satisfies this strength. There were no accidental signs and symbols in Miro's works. They appeared in his paintings and stayed in his artistic world forever moving from one painting to another - a bird, a woman, a star, stairs etc.

\section{CONCLUSION}

Art historians studying Miro's art always highlight his inseparable connection with Catalonia, with his homeland, with Montroig. The place of the first Miro's creative experiments and attempts of self-realization was Barcelona. There he was born, studied, became an artist, learnt about European art in Barcelona's galleries, had his first exhibition and met key people in his life. Everything related to Catalonian land and culture became part of artist's style and formed the essence of his artistic personality. Catalonian Romanesque frescoes with their quite conventional representation of faces and figures keep recognizable features of traditional art which is revealed in animal and plant images as well as everyday life scenes.

Romanesque art which was popular among uneducated people and was part of folk tradition and very emotional at its heart greatly influenced Miro.

\section{REFERENCES}

[1] Zervos K. Contemporaries about Miro // Joan Miro. An Almanach Issue 85. Saint-Petersburg, 2004.

[2] Punyet Miro J., Lolivier-Rahola G., Juan Miro. The Painter from the Stars. Moscow, 2003.

[3] Georges Raillard Conversaciones con Miró. Barcelona, 1998. 